\title{
(60) 高分子科学最近の進歩
}

\section{金属錯体の固相重合}

\author{
トポケミストリーと化学振動現象 \\ としての新局面
}

\section{本田 憲治}

Kenji Honda, 相模中央化学研究所

\section{1.はじめに}

最近超電導で話題を賑わしているセラミックスは, 例えば, $\mathrm{Y}_{2} \mathrm{O}_{3}, \mathrm{BaCO}_{3}, \mathrm{CuO}$ の粉末を混ぜ合わせて合 成する。このような固体の関与する不均一反応は，均 一液相あるいは気相反応に比べ一般に反応論的取り扱 いが難しく，学問的にはまだ十分に整理されていな い.ところが，このような固体化学の分野に扔いて， 溶液反応では得られない特異な反応性あるいは物性を もつ機能材料がしばしば生まれてきた。固体化学の反 応例としては, 無機粉体の焼結, 有機結晶の光反応, 固体マトリックス中での重合などさまざまなものが含 まれるが，共通するねらいは「結晶学的整合性のある 分子集合体」を作ることにある。固相重合も高分子の 高次構造制御の有力な手段として古くから研究がなさ れてきた。本稿では，遷移金属錯体の結晶性固体表面 におけるエピタキシャル成長および高分子固体膜を反 応場とした錯体形成反応を，材料の高次構造制御とい う観点から取り上げた。固液界面のかかわる錯イオン の多核化という共通する点をもつ両者を従来の固相反 応に照らしてみて，これまでとは異なる何か新しい発 想の原点を求め，材料科学に新局面を拓くべく以下の 二つの現象を紹介したい。

\section{2. 固相重合とトポケミストリー}

固相重合の例は枚挙にいとまないが，代表的なもの

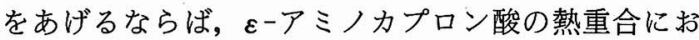
ける 3 次元配向ポリアミドの生成，トリオキサンの

Solid-State Polymerization of Coordination Compounds-Its New Aspects of Topochemistry and Chemical Oscillation-
線固相重合による高結晶性ポリマーの合成，2,5-ジス チリルピラジンに代表される共役ジオレフィンの光四 点固相重合，共役ジアセチレンモノマー結晶から高分 子完全結晶の作製などがある1)。ここではこれらの各 論を詳しく説明することは避けて，固相重合にみられ るトポケミカル現象についてまず簡単に言及したい. 上記のジオレフィンやジアセチレンの重合では，始原 系と生成系の結晶学的整合性が 3 次元的に一致するこ とが知られている。このようなプロセスは “トポタキ シー”とよばれている。一方，始原系と生成系の結晶 学的整合性が 2 次元的な場合は“エピタキシー”とよ

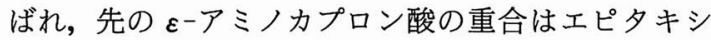
ーである。このようにモノマーを結晶状態においてそ の構成原子の最小限の動きのかなで高次構造を規制し つつポリマーを合成ずアプローチを Schmidt らは “Crystal Engineering”とよんだ2). 本稿でとくに金 属錯体の固相重合を取り上げた理由は，（イ）この種 の化合物は中心金属の無機物性と配位子の有機物性の 両者が混成した反応性および機能性を発現するアトミ ックハイブリッド材料であること，(口）遷移金属錯 体（とりわけ多核白金錯体）は低次元電子-格子系を 構成し，その超格子構造（Super-lattice）を形成する ことにより “配位素子”とよばれる超微細素子を作る 可能性を秘めているこどなど, 今後ますます注目さ れる分子工学の中心課題を包含しているからである。

\section{3. 金属錯体のエピタキシャル成長}

ハロゲン橋かけ型の 1 次元鎖状構造をもつ白金錯体 に代表される一群の混合原子価多核金属錯体が，最 近，新しい超格子構造を形成しうる材料として注目さ れている。この多核白金錯体は, 図 1 に示すように,

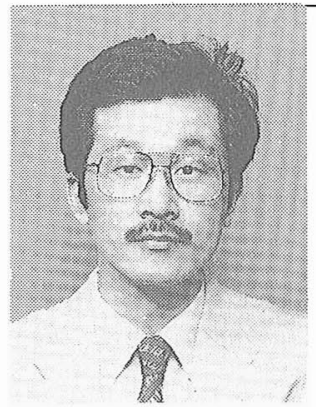

本田罳治 相模中央化学研究所 (229 相模原市西大沼 4) 第 5 研 究班主担・副主任研究員・工博 昭和 46 年早大理工学部応用化 学科卒. 51 年早大大学院博士課 程終了. 51 年 56 年日本赤十字 社中央血液センター研究部, 56〜 59 年米国エネルギー省太 陽エネルギー研究所. 59 年から 現職。専門は高分子化学，材料 科学. 


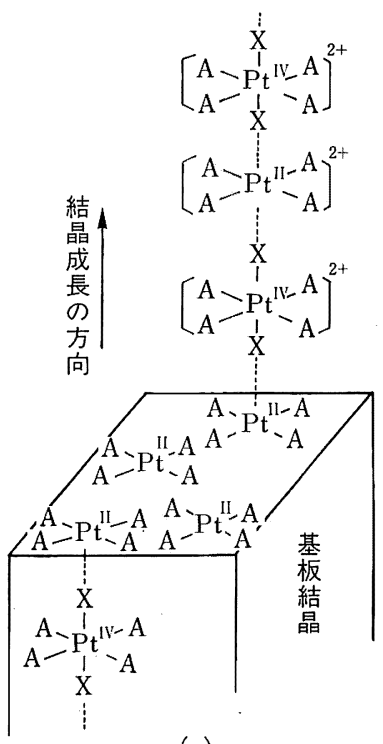

(a)

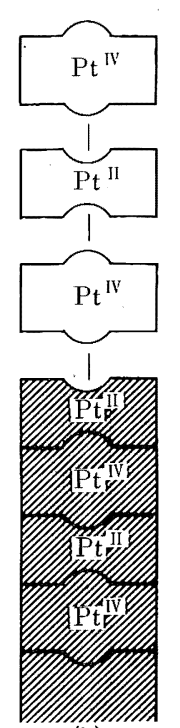

(b)

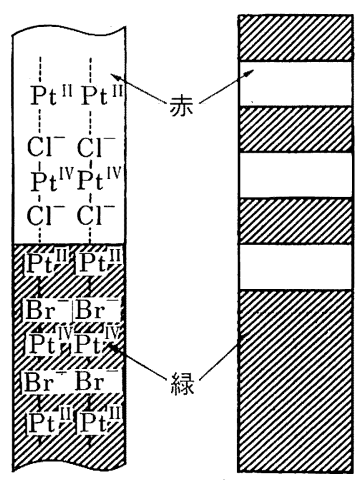

図 1 選択配位エピタキシーの原理図 ${ }^{3)}$

(a) はハロゲン橋かけ型混合原子価 多核白金錯体の骨格構造を示し, Aは中 心金属の平面配位子，Xはアキシャル配 位子（ハロゲンイオン）を表わす。（b ) はエピタキシャル成長の様子をモデル的 に示したもので，(c) は人工格子構造の 模式図である。
2 価の白金原子をもつ錯イオン $\left(\mathrm{Pt}^{\mathrm{H}} \mathrm{A}_{4}\right)^{2+}$ と 4 価の白 金原子をもつ錯イオン $\left[\mathrm{Pt}^{\mathrm{tv}} \mathrm{X}_{2} \mathrm{~A}_{4}\right]^{2+}$ とがハロゲンを 介して交互に結合した錯化合物である。ここで，Aが アルキルアミン，Xが八ロゲン陰イオンである錯体を Wolffram's red salt analogue と称する。この錯体が 多核化する過程で $\left[\mathrm{Pt}^{\mathrm{IV}} \mathrm{X}_{2} \mathrm{~A}_{4}\right]^{2+}$ と $\left[\mathrm{Pt}^{\mathrm{II}} \mathrm{A}_{4}\right]^{2+}$ が結合 する場合，橋かけ配位子 $\mathrm{X}^{-}$が 2 つの白金原子のちょ うど中央に位置すれば， $-\mathrm{Pt}^{\mathrm{III}}-\mathrm{X}^{-}-\mathrm{Pt}^{\mathrm{III}}-\mathrm{X}^{-}-$という “スピン密度波”の状態になると考えられる。ところ が，1 次元系では電子-格子相互作用のためパイエル ス転移を起こし，電荷がひとつおきの白金イオンに局 在化した “電荷密度波”の状態に移行してしまう。す

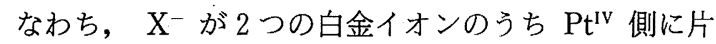
寄った混合原子価状態 $\left(-\mathrm{X}^{-} \cdot \mathrm{Pt}^{\mathrm{Iv}} \cdot \mathrm{X}^{-}-\mathrm{Pt}^{\mathrm{II}}-\mathrm{X}^{-} \cdot \mathrm{Pt}^{\mathrm{tv}}\right.$ ・ $\mathrm{X}^{--}$) として存在する. $\mathrm{X}^{-}$と $\mathrm{Pt}^{\mathrm{II}}$ 間には電荷移動型 相互作用が働くので， $\mathrm{Pt}^{\mathrm{II}}-\mathrm{Pt}^{\mathrm{II}}$ や $\mathrm{Pt}^{\mathrm{IV}}-\mathrm{X}^{-}-\mathrm{X}^{-}-\mathrm{Pt}^{\mathrm{IV}}$ な どのホモカップリングよりも $\mathrm{Pt}^{\mathrm{IV}}-\mathrm{X}^{-}-\mathrm{Pt}^{\mathrm{II}}$ のへテロ カップリングのほうが選択的に起こる.さらに, 配位 子間には弱い van der Waals 力しか働かないので, 配位子を介したへテロカップリングは起こり得ない. このように中心金属イオンの選択的反応性を反映し て, 生成多核錯体は擬 1 次元の異方性構造をとる。

電総研のグループは，金属錯体に特有な金属イオン 一配位子間の配位結合の特性を利用した人工格子構造 構築の概念,「選択配位エピタキシー」を提案し,こ の多核白金錯体を用いたへテロエピタキシャル結晶成 長を報告した ${ }^{3), 4}$. 以下にその概念を示す. 化学式 $\left[\mathrm{Pt}(\mathrm{en})_{2}\right]\left[\mathrm{PtBr}_{2}(\mathrm{en})_{2}\right] \mathrm{Y}_{4}(\mathrm{en}:$ エチレンジアミン,
$\mathrm{Y}: \mathrm{ClO}_{4}^{-}$または $\mathrm{BF}_{4}^{-}$) で表わされる緑色錯体結晶 を基板として, その結晶端面に図 1 に模式的に示した ように $\left[\mathrm{Pt}^{\mathrm{II}}(\mathrm{en})_{2}\right]^{2+}$ と $\left[\mathrm{Pt}^{\mathrm{IV}} \mathrm{Cl}_{2}(\mathrm{en})_{2}\right]^{2+}$ から成る赤 色錯体を結晶成長させた場合, 両錯体は結晶学的に同 形で 1 次元鎖に垂直な面内での格子不整合率が $0.2 \%$ 以下であるため, 緑色結晶上に赤色結晶がへテロ接合 し, エピタキシャル成長する.一方, 組成や結晶構造 などが全く異なる錯体同士では，エピタキシャル成長 は起こらないことが確認されており，多核白金錯体を 用いる結晶成長ではこのような結晶学的整合性, 錯体 分子のもつ結合相補性おるび方位選択性を利用するこ とにより, 種々の人工格子構造の構築が可能になるも のと期待される.

近年, 無機系化合物半導体の分子線エピタキシャル 成長法などが超格子材料を製造する技術として注目さ れているが, 上記の選択配位エピタキシーを無機半導 体のエピタキシャル成長と比較することは興味深い. 例えば，化合物半導体の代表である GaAs のエピ夕 キシャル成長においては，As 原子には反応的異方性 がないため 3 次元格子構造の構築は困難であると考え られる.これに対して, 上記の多核錯体においては, 中心金属イオンの $\mathrm{d}$ 軌道のベクトル的相互作用が極微 細な 3 次元格子を作るうえで効果的に働く可能性があ り, 従来の無機半導体材料とは異なった機能や微細構 造を有する新電子材料を開拓する可能性が指摘されて いる.

高分子の関与するエピタキシーはこのほかにもいく つか知られている。金属錯体を用いた例としては，金 


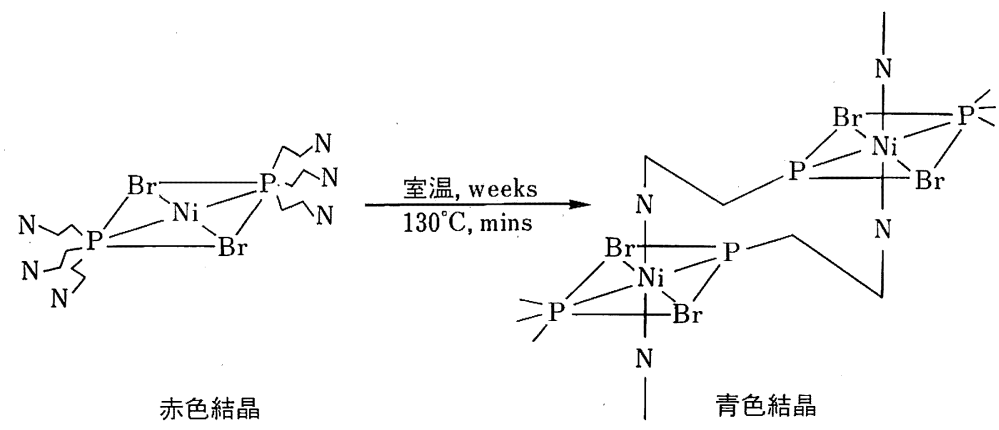

属単結晶表面へのフタロシアニンの気相成長における 分子配向などがあり ${ }^{5)}$, 最近では, テトラシアノベン ゼンを $\mathrm{KCl}, \mathrm{Cu}, \mathrm{Ni}$ などの結晶性基板上に蒸着するこ とにより高分子フタロシアニンー金属錯体を触系状結 晶としてエピタキシャル重合することが報告されてい る ${ }^{6)}$. 固-液相界面での反応としては，シアノコバル トフタロシアニン $\left(\mathrm{K}\left[\mathrm{PcCo}^{\mathrm{III}}(\mathrm{CN})_{2}\right]\right)$ の電界結晶成 長がある. $\mathrm{K}\left[\mathrm{PcCO}^{I I I}(\mathrm{CN})_{2}\right]$ をアセトニトリル中で 電解酸化すると白金電極上に板状結晶が析出し，X線 結晶解析から, Pc-Pc 間距離 3.45 $\AA, \mathrm{Co}-\mathrm{Co}$ 間距離 $7.65 \AA$ で, $\mathrm{C} \equiv \mathrm{N}$ が $\mathrm{Pc}$ 面内 $\mathrm{Co}$ 原子上に垂直に立つ た分子パッキングのよい高導電性の結晶が得られるこ とが報告されている7). 完全固相系の例としては，式 （1）に示すような反応が知られている8).この固相重

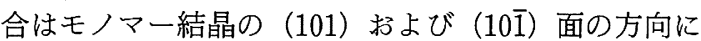
沿ってトポタキシャル的に進行するとされている．興 味あることには，赤色のモノマー結晶が重合にともな って青色に変化し，その変色域はモノマー結晶の （001）面に沿って成長する。

\section{4. 固相反応にみられる振動現象}

固相反応の特徵のひとつに，反応系が時間座標およ び空間座標によって表現されることがある。一般に は，均一液相および気相反応は時間の関数として表わ されるスカラ的現象である。これに対して不均一固相 反応はべクトル的現象で，このような系では空間的振 動現象が観測される場合がある. 代表例として，2つ またはそれ以上の可溶性イオン種がゲル固相中を拡散 して不溶性塩を生成するときに沈殿物が周期的に析出 する “リーゼガング現象”をあげることができる。拡 散という動的状態において秩序構造が形成されるとい うことは一見理解しにくい事象であるが, Prigogine らの非平衡熱力学の理論9)によって，このような散逸 現象が理論的に説明できるようになった。

筆者らは, $\mathrm{Fe}^{2+}$ と $\mathrm{Fe}(\mathrm{CN})_{6}{ }^{3-}$ から成るプルシアン ブルー $(\mathrm{PB})$ に代表されるシアノ橋かけ 3 次元錯体の 固相生成を研究してきた ${ }^{10)}$. 図 2 に示したプロセスに
従い, $\mathrm{Fe}^{2+}$ と $\mathrm{Fe}(\mathrm{CN})_{6}{ }^{3-}$ をナフォン膜（含フッ素 陽イオン交換膜：以下 Nf と略す）中で拡散させ重合 した。プロセス（A）では，まず $\mathrm{Nf}$ 中に $\mathrm{Fe}^{2+}$ を吸着 させ, 次に膜を $\mathrm{Fe}(\mathrm{CN})_{6}{ }^{3-}$ を含む水溶液に浸漬した ところ， $\mathrm{PB}$ は $\mathrm{Nf}$ 表面にのみ析出した。 プロセス (B) では先に Nf 中に $\mathrm{Fe}(\mathrm{CN})_{6}{ }^{3-}$ を中性塩として含 浸させ，次に $\mathrm{Fe}^{2+}$ を含む水溶液に膜を浸漬したとこ ろ, プロセス (A) とは逆に PB は Nf 内部に析出し た.さらにプロセス (C) では, $\mathrm{Fe}^{2+}$ と $\mathrm{Fe}(\mathrm{CN})_{6}{ }^{3-}$ $\mathrm{Nf}$ を介して同時に対向拡散させたところ，PB は比 較的幅の広い 1 本の带状に析出した。このように各成 分イオンの固相内における拡散の速度と方向性によっ て生成物の析出位置が決定されることがわかった。こ こで興味あることに，図 2-B (写真) に示すように， プロセス（B）において各成分イオンの濃度をある特 定の範囲内におさめると, $\mathrm{PB}$ が Nf 膜内で周期的多 層状に析出することが見いだされた ${ }^{11)}$.これは先に述 ベたゲル中でのリーゼガング現象と基本的には同じも のであるが，ゲル中では比較的広い周期幅であったの に対して，薄膜固相中では周期幅は狭く，“ミクロリ 一ゼガング現象”とよぶにふさわしい. このようなミ クロ現象が意味をもつのは，とくにその応用面にあ る.すなわち, 図 2-B.に示した複合膜は, 周期幅に 対応する波長の光に対して複屈折を示すので，光変調 素子への利用が可能である。一方，図 2-A のような 表面析出型の膜は固体電気化学素子として有用である ことがすでに認められている12)

$\mathrm{PB}$ のような高分子金属錯体ではないが，低分子塩 の集合体（コロイド）が高分子固体膜中で生成する際 にも，上記のような散逸構造を形成することが知られ ている。例えば， AgI などのハロゲン化銀をポリビニ ルアルコール ${ }^{13)}$ あるいはナフィオン ${ }^{14)}$ の膜中で $\mathrm{Ag}^{+}$ とハロゲンイオンを反応させて作った場合, ハロゲン 化銀のコロイドが膜断面に垂直方向に $1 \mu \mathrm{m}$ またはそ れ以下の周期幅で多数帯状に析出することが観察され ている、また, 人工藏器のカルシケーションにおいて も類似の現象がみつかっている，人工心臓の表面層は 

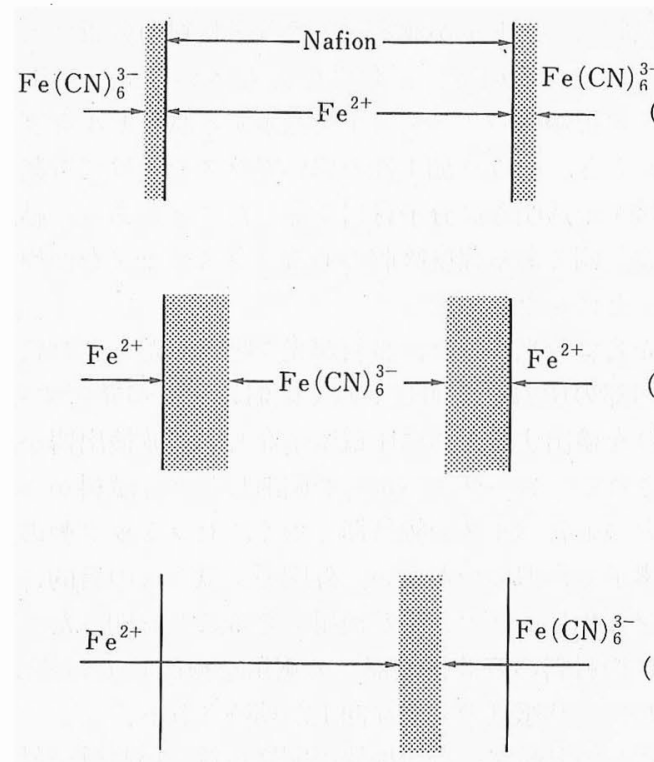

ヘパリンを結合した負荷電性ハイドロゲルで覆われて いるが，これが血液と接触して 20 日間ほど経過する と，ゲル層に第二リン酸カルシウムの沈殿が周期的多 層に出現する，これは，血中の $\mathrm{Ca}^{2+}$ がまずゲル中に 取り込まれ，つづいてリン酸根がゲル中にゆっくり拡 散する過程で形成されるものと考えられている ${ }^{15)}$ 。こ のような化学振動現象は一見特異なものとして映る が，ある反応種および反応場に対して特定の条件が満 たされるならば，普遍的に起こる現象といえる。

\section{5. 結 語}

以上のように固相反応（主として金属錯体の多核形 成反応）におけるトポケミカル現象と振動現象という 相互にあまり脈絡のないようにみえる事象について記 述したが，実はこれらの関係は Graham が 1961 年に コロイドの概念を初めて世に出した論文の中で述べて いる二つの事柄の関係と対比してみると興味深い： 「コロイドとクリスタロイドの両者はあたかも別々の 物質の世界をかまえているような外観を呈して，ケミ カルサイエンスの中にそれ相応の領域を作っている」. ここでいうクリスタロイドの領域とは，いわば静的状 態における秩序性の世界であって，コロイドの領域は 動的状態のそれといえる，留意するべき点は，化学反 応における秩序性発現という概念の中で両者には共通 するものがあるということである．固相反応にみられ る上記の二つの現象も，同じょうに共通する概念のも とに整理できるものと思われる。これからの化学が目 指すべき方向が物質の高次構造の精密制御にあること を考えるとき，本稿に記した二つの現象がこれからの

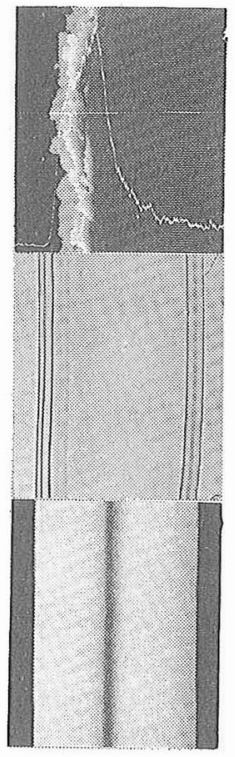

図 2 プルシアルブルーのナフィオ ン固相における生成過程と複 合膜の構造

（A）は逐次浸漬法 (I)，（B）は逐 次浸漬法 (II)，および (C) は対向拡 散法のプロセスを示し, 写真は各法 で得られる膜断面の顕微鏡観察の結 果である.
新展開に示唆するものは大きいと考えられる.

最後に，本稿の執筆にあたり助言を賜った電子技術 総合研究所 八百隆文および高橋和宏両博士ならびに 繊維高分子材料研究所 松田宏雄博士に感謝の意を表 します。

\section{文献}

1）中西八郎：「分子集合体一その組織化と機能」(化学総 説 No. 40), 日本化学会編, 1983, p.29

2) G.M.J. Schmidt : Pure Appl. Chem., 27, 647 (1971)

3）谷野浩史，他：応用物理, 55, 943 (1986)；高橋和宏, 他: 化学と工業, 40, 135 (1987)

4) H. Tanino, et al.: Jpn. J. Appl. Phys., 25, L571 (1986) ; ibid., 26, L97 (1987) ; ibid., 26, L983 (1987)

5) J.C. Buchholz, G.A. Somorjai : J. Chem. Phys., 66, 573 (1977)

6）芦田道夫，他：日化第 50 春季年会, 2A10，2A11（1985）

7) Y. Orihashi, et al.: Synth. Met., 19, 751 (1987)

8) K. Cheng, B.M. Foxman: J. Am. Chem. Soc., 99, $8102(1977)$

9) P. Glansdorff, I. Prigogine: "Thermodynamic Theory of Structure, Stability and Fluctuations", Wiley -Interscience (1971)

10) K. Honda, et al.: J. Chem. Soc., Chem. Commun., 168 (1986) ; Polymer Prep., Jpn., 35 (5), 1818 (1986)

11) K. Honda, et al.: IUPAC CHEMRAWN VI Conference, II H03 (1987)

12）本田憲治, 桑野敦司, 高分子論文集 : 43, 721 (1986)； K. Honda, H. Hayashi : J. Electrochem. Soc., 134, 1330 (1987)

13) K.F. Mueller: Science, 225, 1021 (1984)

14) L.E. Manring, S. Mazur: J. Phys. Chem., 90, 3269 (1986)

15）森 有一: 私信 (1987) 